\title{
Pengaruh Penggunaan Pendekatan Value Clarification Technique (VCT) Model Matriks terhadap Hasil Belajar Tematik Terpadu di Kelas IV Sekolah Dasar
}

\author{
Lili Rahmawati ${ }^{1)}$, Reinita ${ }^{2)}$ \\ Pendidikan Guru Sekolah Dasar, Universitas Negeri Padang, Indonesia \\ Email: 1)ilirahmawati0298@gmail.com , ${ }^{2}$ reinita reinita@yahoo.com
}

\begin{abstract}
Abstrak
Penelitian ini bertujuan untuk mengetahui pengaruh penggunaan pendekatan Value Clarification Technique model Matriksterhadap hasil belajar tematik terpadu kelas IV SDN 05 Pasar Baru Kecamatan Bayang Pesisir Selatan. Jenis penelitian ini adalah penelitian kuantitatif dengan jenis eksperimen dan desain penelitian quasi eksperimen bentuk nonequivalent control group design..Teknik pengambilan sampel yang digunakan adalah Nonprobability Sampling dengan jenis Purposive sampling. Sampel dalam penelitian ini adalah siswa kelas IV SDN 05 Pasar Baru Kecamatan Bayang Pesisir Selatan pada kelas $I V_{B}$ sebagai kelas eksperimendan kelas $\mathrm{IV}_{\mathrm{A}}$ sebagai kelas kontrol yang masing-masing berjumlah 20 siswa. Berdasarkan hasil penelitian diperoleh nilai rata-rata kelas eksperimen sebesar 76,60 dengan standar deviasi yaitu 11,73 dan nilai rata-rata kelas kontrol sebesar 65,50 dengan standar deviasi yaitu 17,47. Berdasarkan perhitungan uji-t (t-test) diperoleh $t_{\text {hitung }} 2,33$ sedangkan $t_{\text {tabel }}$ pada taraf kepercayaan $\alpha 0,05$ adalah 2,024 sehingga $t_{\text {hitung }}>t_{\text {tabel }}$. Dapat disimpulkan penerapan pendekatan Value Clarification Technique model Matriks berpengaruh terhadap hasil belajar tematik terpadu di kelas IV SDN 05 Pasar Baru Kecamatan Bayang Pesisir Selatan.
\end{abstract}

Kata Kunci: Value Clarification Technique Model Matriks, Hasil Belajar, Pembelajaran Tematik Terpadu

\begin{abstract}
This study aims to determine the effect of using the Value Clarification Technique Matrix model approach on integrated thematic learning outcomes for class IV SDN 05 Pasar Baru, Bayang Pesisir Selatan District. The type of this research is quantitative research with experimental type and quasi-experimental research design in the form of nonequivalent control group design. The sampling technique used is nonprobability sampling with purposive sampling type. The sample in this study were fourth grade students of SDN 05 Pasar Baru, Bayang Pesisir Selatan sub-district in class $\mathrm{IV}_{\mathrm{B}}$ as the experimental class and class $\mathrm{IV}_{\mathrm{A}}$ as the control class, each of which totaled 20 students. Based on the results of the study, the experimental class mean value was 76.60 with a standard deviation of 11.73 and the control class mean value was 65.50 with a standard deviation of 17.47. Based on the calculation of the t-test (t-test), it was obtained t count 2.33 while $t$ table at the level of confidence $\alpha 0.05$ was 2.024 so that $t$ count $>t$ table. It can be concluded that the application of the Value Clarification Technique Matrix model approach affects the integrated thematic learning outcomes in class IV SDN 05 Pasar Baru Kecamatan Bayang Pesisir Selatan.
\end{abstract}

Keywords:Value Clarification Technique Matrix Model, Learning Outcomes, IntegratedThematicLearning

\section{PENDAHULUAN}

Pendekatan Value Clarification Technique (VCT) merupakan pendekatan yang menekankan kepada nilai-nilai sikap yang dibentuk melalui aktifitas-aktifitas berfikir kritis terhadap suatu permasalahan yang dialami oleh siswa dalam kehidupan sehari-harinya. 
Pendekatan Value Clarification Technique (VCT) merupakan pendekatan pembinaan nilai sikap pada diri siswa melalui proses mencari, menentukan dan menganalisis suatu nilai yang dianggap baik oleh siswa.(Taniredja : 2015)

Pendekatan pembelajaran VCT sangat identik dengan pembelajaran nilai, yaitu pendekatan pembelajaran yang berupaya untuk menumbuhkembangkan nilai/sikap mulia pada diri siswa. Nilai-nilai tersebut dibangun dalam proses pembelajaran yang melibatkan siswa secara aktif untuk menganalisis suatu permasalahan yang diberikan. Adisusilo (2014:141) mengemukakan bahwa "VCT merupakan pendekatan pendidikan nilai dimana siswa dilatih untuk menemukan, memilih, menganalisis, memutuskan, dan mengambil sikap sendiri nilai-nilai hidup yang ingin diperjuangkannya." Siswa dibimbing untuk mampu menganalisis dan mengklarifikasikan nilai-nilai dalam kehidupan sehari-harinya melalui stimulus yang diberikan oleh guru dalam pembelajaran.

Pendekatan VCT memiliki beberapa model yang dapat diterapkan sesuai dengan materi pembelajaran yang dianggap relevan oleh guru. Salah satunya ialah VCT model matriks atau daftar. Ahmad Khosasi Djahiri (dalam Reinita, 2017) menyatakan bahwa VCT model matriks berorientasi pada pembentukan sifat luhur dalam diri siswa melalui stimulus yang disampaikan lewat media daftar atau tabel sikap. Dimana dari daftar sikap ini akan dapat melibatkan perasaan siswa dalam menghayati permasalahan dan menyentuh hati siswa yang bermuara pada lahirnya argumen dan kemampuan siswa memahami nilai/konsep yang dipelajari.

Pendekatan VCT model matriks cocok untuk diterapkan pada pembelajaran yang berhubungan pembinaan nilai/sikap, karena fokus utama dari pendekatan ini ialah pembentukan aspek sikap pada diri siswa. Menurut Reinita (2017)Penerapan pendekatan VCT model matriks yang menggunggulkan penguasaan nilai-nilai karakter diharapkan dapat menumbuhkembangkan literasi budaya dan nilai-nilai kewarganegaraan dalam pembelajaran. Pendekatan ini dapat diterapkan dalam pembelajaran kurikulum 2006 ataupun pembelajaran kurikulum 2013. Khusus kurikulum 2013, guru harus mencari pembelajaran yang mengaitkan minimal bidang studi PKn, IPS dan Bahasa Indonesia. Maka dari itu penting bagi guru untuk menganalisis tema terlebih dahulu dan memperhatikan KD yang memang cocok untuk penerapan VCT model matriks ini.

VCT model matriks sebagai sebuah pendekatan pembelajaran tentunya memiliki keunggulan tersendiri. Menurut Djahiri (dalam Reinita : 2017) pembelajaran VCT memiliki beberapa keunggulan untuk mengoptimalkan pembelajaran afektif karena: (1) VCT dapat membina dan mempribadikan nilai moral, (2) dapat mengklarifikasi dan mengungkapkan isi pesan nilai moral, (3) dapat mengklarifikasi kualitas nilai moral diri siswa dan nilai moral dalam kehidupan nyata, (4) dapat mengundang, melibatkan, membina, dan mengembangkan potensi diri siswa, (5) dapat memberikan pengalaman belajar, (6) dapat menangkal, meniadakan, mengintervensi dan melakukan subversi terhadap nilai-moral yang ada dalam sistem nilai dan moral yang ada dalam diri seseorang, dan (7) dapat menuntun dan memotivasi hidup secara layak dan bermoral tinggi.

Dengan pendekatan VCT ini, sifat-sifat yang luhur akan benar-benar tertanam dalam diri siswa dan dapat diimplementasikan dalam kehidupannya sehari-hari. karena penerapan pendekatan VCT hakikatnya tidak hanya berupa penyampaian pengetahuan tentang sikap baik-buruk semata, namun juga analisis yang mendalam dari siswa terhadap informasi yang diterima sehingga siswa mampu memilah dan memilih tindakan yang seharusnya dilakukan sesuai dengan nilai dan norma yang berlaku.

Pada jenjang pendidikan dasar, penerapan pembelajaran kurikulum 2013 dilaksanakan melalui pembelajaran tematik terpadu. Pembelajaran tematik terpadu ditujukan agar siswa dapat aktif dan mampu mengembangkan potensinya dalam pembelajaran, karena konsep pembelajaran tematik terpadu ialah pembelajran yang berpusat pada siswa (student center). Hal ini sesuai dengan yang dikemukakan oleh (Majid, 2014) bahwa pembelajaran tematik terpadu berpusat pada siswa ditujukan untuk keaktifan siswa dalam pembelajaran secara mental maupun koqnitifnya berdasarkan pengetahuan dan potensi yang telah dimilikinya. 
Dalam upaya menerapkan pembelajaran tematik terpadu, sangat diperlukan kemampuan manajemen yang baik dari seorang guru. Karena dengan manajemen yang baik dan teratur akan memudahkan guru dalam melaksanakan tugasnya sebagai pendidik. Guru diharapkan mampu untuk memetakan pendekatan dan metode pembelajaran sedemikian rupa agar tujuan pembelajaran tematik terpadu yang diharapkan dapat tercapai dan hasil belajar tercapai maksimal. Salah satunya penggunaan model pembelajaran.Model pembelajaraan merupakan kerangka kerja konseptual yang menggambarkan prosedur sistematis dalam mengatur pengalaman belajar untuk mencapai tujuan pembelajaran.(Reinita, Suarman, \& Sakdiah, 2020)Hasil belajar merupakan kemampuan yang diperoleh peserta didik setelah melalui kegiatan belajar (Abdurrahman dalam Jihad \& Haris: 2013). Sejalan dengan Yusuf (2015:181) "Hasil belajar merupakan wujud pencapain peserta didik; sekaligus merupakan lambang keberhasilan pendidik dalam membelajarkan peserta didik". Setiap proses belajar yang dilalui peserta didik akan memperoleh hasil belajar. Peningkatan kualitas proses belajar dapat dilihat pada kualitas hasil belajar siswa.(Abidin, 2018).

Banyak faktor yang dapat mempengaruhi hasil belajar yang diperoleh. Salah satunya dengan menggunakan pendekatan Value Clarification Technique (VCT) model matriks yang dapat diterapkan pada pembelajaran tematik terpadu di Sekolah Dasar. Dengan menerapkan model ini diharapkan dapat membuat siswa lebih aktif dalam belajar, mendorong motivasi belajar siswa dan menumbuhkembangkan nilai/sikap mulia pada diri siswa.

Sejalan dengan pemaparan diatas, berdasarkan penelitian yang telah dilakukan oleh Novita (2019) dalam pengaruh model pembelajaran VCT (Value Clarification Technique) terhadap hasil belajar mata pelajaran PKn menunjukkan bahwa: terdapat pengaruh yang signifikan penggunaan model pembelajaran VCT (Value Clarification Technique) terhadap hasil belajar siswa kelas V MIN 12 Medan. Sedangkan penelitian yang telah dilakukan Halimatun Sakdiah (2019) dalam pengaruh penggunaan pendekatan Value Clarification Technique (VCT) metode percontohan terhadap hasil belajar siswa pada pembelajaran PKN di sekolah dasar". Hasil penelitian menunjukkan bahwa Pendekatan Value Clarification Technique (VCT) metode percontohan berpengaruh terhadap hasil belajar PPKn siswa kelas V SDN Gugus VI Kecamatan Akabiluru Kabupaten Lima Puluh Kota. Selanjutnya penelitian yang telah dilakukan oleh Reinita (2017) dalam peningkatan penerapan nilai karakter bangsa mengguakan pandekatan VCT model daftar berorientasi Reading Literacy pada pembelajaran PKn siswa kela IV sekolah dasar. Menunjukkan hasil penelitian dengan kriteria sangat baik.

Berdasarkan pengamatan penulis pada saat observasi di kelas IV SDN 05 Pasar Baru Kecamatan Bayang Pesisir Selatan pada bulan Agustus 2020 pada tema 1 (Indahnya Kebersamaan), subtema 3 (peredaran darahku sehat), pembelajaran 1, 2 dan 3, mata pelajaran yang terkait Bahasa Indonesia, IPA, SBdP, PPKn dan IPS. Masalah yang penulis lihat di lapangan yaitu di dalam rpp tertulis guru menggunakan pendekatan saintifik pada pembelajaran tematik terpadu, namun pada pelaksanaannya belum sesuai dengan langkahlangkah yang ada pada pendekatan saintifik, masih didominasi dengan ceramah yang berpusat pada guru. Sehingga peserta didik belum termotivasi saat belajar, membuat peserta didik menjadi lebih cepat bosan, dan kurangnya keterlibatan peserta didik secara aktif sehingga berdampak pada hasil belajar yang diperoleh oleh siswa. Menurut Faisal (2013) pendekatan saintifik merupakan suatu pendekatan yang digunakan dalam pembelajaran dengan menitikberatkan pada penggunaan metode ilmiah dalam proses pembelajaran, dimana siswa dituntut untuk berfikir ilmiah, logis, kritis dan objektif. Adapun langkah-langkah pendekatan saintifik adalah mengamati, menanya, mengumpulkan informasi, menalar dan mengkomunikasikan. Pada pembelajaran kelas tinggi seharusnya guru tidak hanya menggunakan pendedekatan saintifik saja. Karena pendekatan saintifik adalah pendekatan yang cocok dan biasa diterapkan di kelas rendah. Untuk itu guru harus bisa memilih pendekatan, model dan metode yang lebih bervariasi dan cocok diterapkan di kelas tinggi. Salah satunya adalah pendekatan Value Clarification Tehcnique Model Matriks 
yang mampu memberikan pemahaman pengetahuan, pembinaan sikap dan pengalaman langsung terhadap siswa.

Berdasarkan permasalahan yang terjadi pada pelaksanaan pembelajaran tematik terpadu yang dikemukakan diatas, maka perlunya dilakukan upaya untuk meningkatkan hasil belajar melalui pendekatan pembelajaran yang sesuai dengan kondisi tersebut. Penulis akan melakukan penelitian dengan mengangkat judul "Pengaruh Penggunaan Pendekatan Value Clarification Technique (VCT) Model Matriks Terhadap Hasil Belajar Tematik Terpadu di Kelas IV SDN 05 Pasar Baru Kecamatan Bayang Pesisir Selatan."

\section{METODE PENELITIAN}

Jenis penelitian ini menggunakan penelitian kuantitatif. Penelitian kuantitatif menggunakan angka-angka dan analisis statistik. Arikunto (2014) menyatakan bahwa penelitian kuantitatif adalah penelitian yang banyak menggunakan angka mulai dari pengumpulan data, penafsiran terhadap data yang telah dikumpulkan dan penampilan hasilnya. Selain itu menurut Sugiyono (2017: 7) "metode kuantitatif dinamakan metode tradisional, karena metode ini sudah cukup lama digunakan sehingga sudah mentradisi sebagai metode untuk penelitian. Metode ini sebagai metode ilmiah/scientific karena telah memenuhi kaidah-kaidah ilmiah yaitu konkrit/empiris, obyektif, terukur, rasional, dan sistematis. Metode ini disebut metode kuantitatif karena data penelitian berupa angka-angka dan analisis menggunakan statistik".

Jenis metode penelitian yang digunakan pada penelitian ini adalah metode penelitian eksperimen. Menurut Sugiyono (2017: 72) "metode penelitian eksperimen merupakan suatu metode penelitian yang bertujuan untuk mencari pengaruh dari perlakuan tertentu terhadap variabel yang lain dalam keadaan yang terkendalikan".

Penelitian eksperimen yang akan dilakukan yaitu Quasi Experimental. Menurut Sugiyono (2017:77) "Quasi Experimental mempunyai kelompok kontrol, tetapi kelompok ini tidak dapat mengendalikan sepenuhnya variabel-variabel luar yang mempengaruhi pelaksanaan kelompok eksperimen". Berdasarkan metode penelitian yang digunakan, maka objek dari penelitian yang akan dilakukan terdiri dari dua kelas yaitu kelas kontrol dan kelas eksperimen. Desain penelitian yang akan digunakan yaitu nonequivalent control group design.

Populasi dari penelitian yang akan dilaksanakan yaitu seluruh siswa kelas IV SDN 05 Pasar Baru Kecamatan Bayang Pesisir Selatan pada semester ganjil tahun ajaran 2020/2021.

Teknik pengambilan sampel yang digunakan adalah adalah Nonprobability sampling. Menurut Sugiyono (2017: 218) "Nonprobability sampling adalah teknik pengambilan sampel yang tidak memberikan peluang atau kesempatan yang sama bagi setiap unsur (anggota) populasi untuk dipilih menjadi anggota sampel". Teknik Nonprobability sampling yang digunakan ialah Purposive Sampling. Menurut Sugiyono (2017:83) "teknikPurposive Sampling, yaitu teknik penentuan sampel dengan pertimbangan tertentu". Penentuan sampel ini didasarkan pada beberapa pertimbangan yaitu sebagai berikut : (1) Keterbatasan waktu, tenaga dan dana sehingga tidak dapat mengambil sampel yang besar dan jauh, (2) SDN 05 Pasar Baru Kecamatan Bayang Pesisir Selatan memiliki 2 rombel di kelas IV, (3) Jumlah siswa kelas IV untuk kedua kelas sama, (4) Karakteristik siswa pada masing-masing kelas relative sama, karena rata-rata siswa berasal dari lingkungan yang berdekatan.

Berdasarkan pendapat di atas maka sampel dalam penelitian ini adalah siswa kelas IVB sebagai kelas eksperimen dan siswa kelas IVA sebagai kelas control yang masingmasing kelas berjumlah 20 siswa.

Metode pengumpulan data yang digunakan dalam penelitian ini adalah tes hasil belajar tematik terpadu. Uji coba instrumen tes yang digunakan yaitu uji validitas (validitas butir) dengan menggunakan rumus korelasi product moment, uji reliabilitas dengan menggunakan rumus Spearman-Brown, uji daya beda soal dan uji taraf kesukaran soal. Analisis data menggunakan uji prasyarat analisis, dan uji hipotesis. Uji prasyarat analisis yang digunakan adalah uji normalitas dan uji homogenitas. Untuk menguji normalitas 
digunakan metodeliliefors dan untuk menguji homogenitas digunakan metode fisher, sedangkan untuk menguji hipotesis digunakan uji t ( $t$-test).

\section{HASILPENELITIAN \\ Deskripsi DataPretest}

Data pretest diperoleh dari tes awal sebelum diberikan pembelajaran menggunakan pendekatan Value Clarification Tehcnique Model Matrikspada kelas eksperimen, dan siswa kelas kontrol menggunakan metode Konvensional. Nilai pretest kelas eksperimen dan kelas kontrol dapat dilihat pada tabel 1, berikut:

Tabel 1. Deskripsi Data HasilPretest Kelas Eksperimen dan Kelas Kontrol

\begin{tabular}{|c|c|c|}
\hline $\begin{array}{c}\text { Pretest } \\
\text { Deskripsi }\end{array}$ & \multicolumn{2}{|c|}{ Kelas Kelas } \\
\hline $\mathrm{N}$ & $20 \quad 20$ & \\
\hline Nilai Tertinggi & & 80 \\
\hline Nilai Terendah & 17 & 30 \\
\hline Rata-rata & 50,60 & 52,45 \\
\hline SD & 19,27 & 13,18 \\
\hline $\mathrm{SD}^{2}$ & 371,33 & 173,71 \\
\hline
\end{tabular}

Berdasarkan tabel diatas, kelas eksperimen dengan jumlah anak 20 orang memperoleh nilai tertinggi 87 dan nilai terendah17. Dari nilai kelas eksperimen diperoleh rata- rata nilai sebesar 50,60, standar deviasi 19,27 dan nilai varians 371,33 . Sedangkan kelas kontrol dengan jumlah anak 20 orang memperoleh nilai tertinggi 80 dan nilai terendah30. Dari nilai kelas kontrol diperoleh rata-rata nilai sebesar 52,45 , standar deviasi 13,18 dan nilai varians 173,71 .

Hal ini menunjukan bahwa perolehan nilai pretest kelas eksperimen lebih rendah dibandingkan dengan kelas kontrol. Untuk lebih jelasnya dapat di lihat pada gambar di bawah ini:

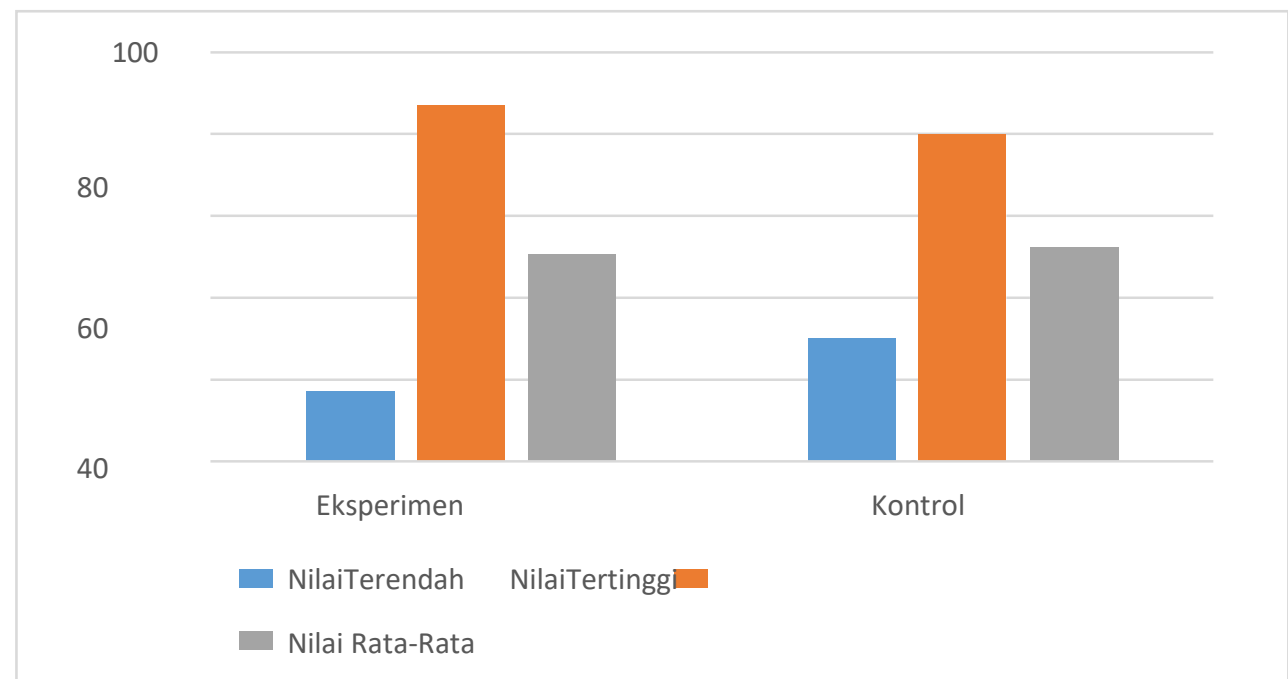

Gambar 1. Grafik Perbandingan Hasil Pretest Kelas Eksperimen dan Kelas Kontrol.

\section{Deskripsi Data Posttest}

Data Posttest diperoleh dari tes akhir setelah diberikan pembelajaran menggunakan pendekatan Value Clarification Technique (VCT) model matrikspada kelas eksperimen, dan siswa kelas kontrol menggunakan metode Konvensional. Nilai Posttest kelas eksperimen 
dan kelas kontrol dapat dilihat pada tabel 2,berikut:

Tabel 2. Deskripsi Data Hasil Posttest Kelas Eksperimen dan Kelas Kontrol

\begin{tabular}{ccc}
\hline Deskripsi & Posttest & \\
\cline { 2 - 3 } & $\begin{array}{c}\text { Kelas } \\
\text { Eksperimen }\end{array}$ & $\begin{array}{c}\text { Kelas } \\
\text { Kontrol }\end{array}$ \\
\hline $\mathrm{N}$ & 20 & 20 \\
\hline $\begin{array}{c}\text { Nilai } \\
\text { Tertinggi }\end{array}$ & 97 & 93 \\
\hline $\begin{array}{c}\text { Nilai } \\
\text { Terendah }\end{array}$ & 53 & 43 \\
\hline Rata-rata & 76,60 & 65,50 \\
\hline SD & 11,73 & 17,37 \\
\hline SD & 137,59 & 305,20 \\
\hline
\end{tabular}

Berdasarkan tabel di atas, kelas eksperimen dengan jumlah anak 20 orang memperoleh nilai tertinggi 97 dan nilai terendah53. Dari nilai kelas eksperimen diperoleh rata- rata nilai sebesar 76,60 , standar deviasi 11,73 dan nilai varians 137,59 . Sedangkan kelas kontrol dengan jumlah anak 20 orang memperoleh nilai tertinggi 93 dan nilai terendah43. Dari nilai kelas kontrol diperoleh rata-rata nilai sebesar 65,50, standar deviasi 17,47 dan nilai varians 305,20 .

Hal ini menunjukan bahwa perolehan nilai posttest kelas eksperimen lebih tinggi dibandingkan dengan kelas kontrol. Untuk lebih jelasnya dapat di lihat pada gambar di bawah ini:

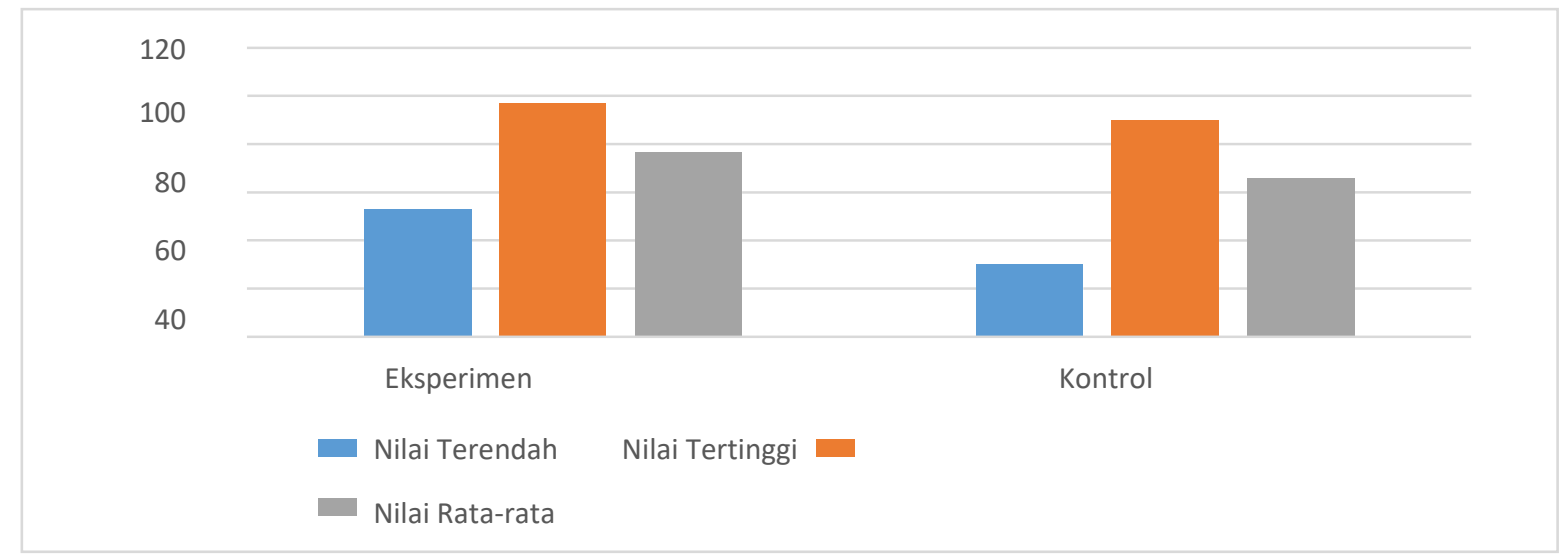

Gambar 2. Grafik Perbandingan Hasil Posttest Kelas Eksperimen danKelas Kontrol

Selanjutnya berdasarkan pengukuran pretest dan posttest kelas eksperimen dan kelas kontrol, terdapat perbedaa perolehan nilai antar kedua kelas. Perbandingan nilai pretest dan nilai posttest antara kelas eksperimen dan kelas kontrol dapat dilihat pada tabel berikut.

Tabel 3. PerbandinganNilaiPretest dan Posttest antara Kelas Eksperimen danKontrol

\begin{tabular}{c|l|c|c|c}
\hline \multirow{2}{*}{ No } & \multirow{2}{*}{ Kelompok } & \multicolumn{2}{|c|}{ Nilai rata-rata } & Peningkatan \\
\cline { 3 - 5 } & & Pretest & Posttest & \\
\hline $\mathbf{1 .}$ & Eksperimen & 50,60 & 76,60 & $\mathbf{2 6 , 0 0}$ \\
\hline $\mathbf{2 .}$ & Kontrol & $\mathbf{5 2 , 4 5}$ & $\mathbf{6 5 , 5 0}$ & $\mathbf{1 3 , 0 5}$ \\
\hline
\end{tabular}


Berdasarkan tabel di atas perbandingan nilai pretest dan posttest kelas eksperimen dan kelas kontrol dapat disajikan dalam bentuk histogram berikut.

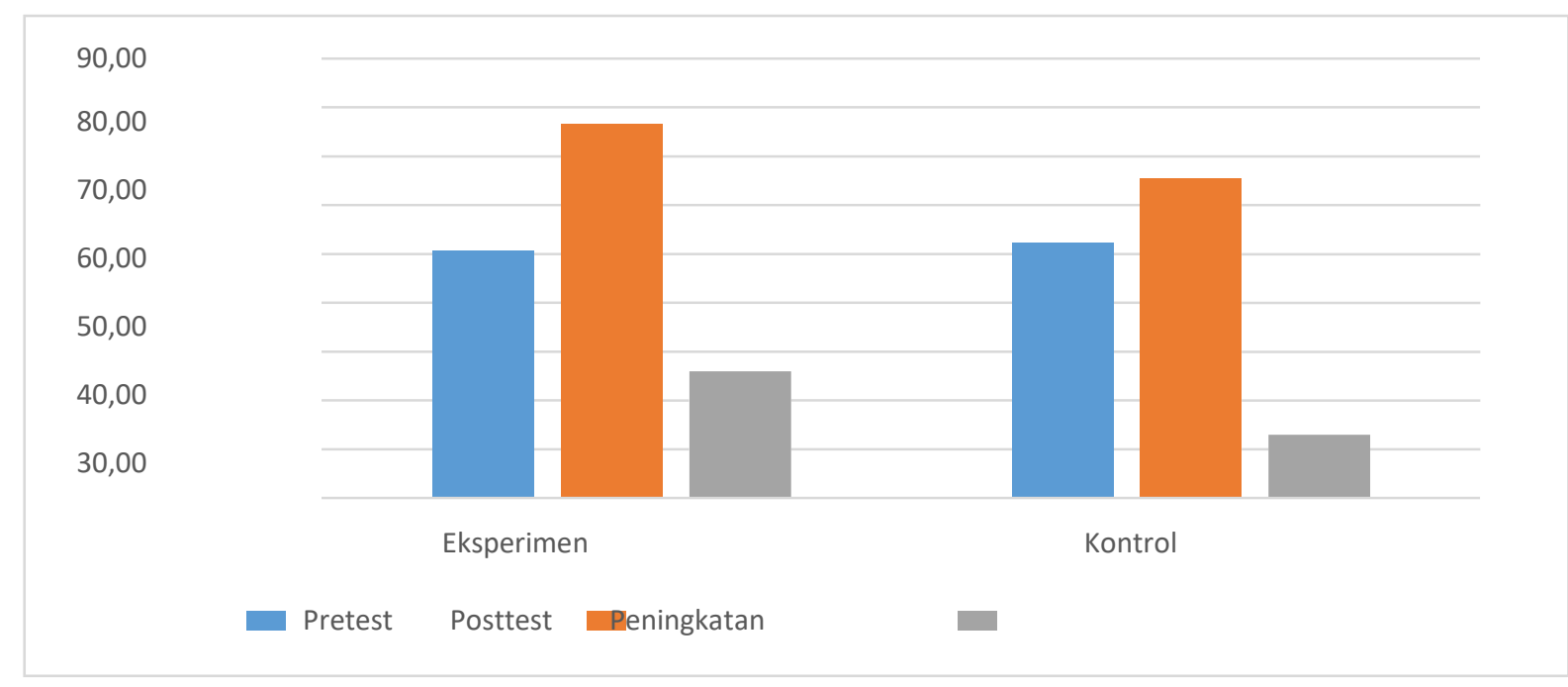

\section{Gambar 3.GrafikPerbandingan Hasil Pretestdan Posttest Kelas Eksperimen dengan KelasKontrol}

Berdasarkan tabel dan diagram diatas dapat dilihat bahwa terdapat perbedaan capaian nilai dari kedua kelas. Peningkatan nilai kelas eksperimen lebih tinggi dari nilai kelas kontrol. Hal ini menunjukkan bahwa pembelajaran menggunakan pendekatan Value Clarification Technique (VCT) model matriksdi kelas IV SD Negeri 05 Pasar Baru Kecamatan Bayang Pesisir Selatan dapat memberikan pengaruh yang lebih baik dibandingkan dengan metode konvensional.

\section{Uji Prasyarat Analisis Uji Normalitas}

Uji normalitas dengan menggunakan uji Liliefors untuk menguji apakah data pretest dan posttest kedua kelas sampel yang diperoleh berasal dari data yang berdistribusi normal atau tidak pada taraf signifikasi $\alpha=0.05$. Berikut tabel 4 adalah hasil perhitungan Uji normalitas dengan kriteria jika Lo < Lt artinya data berdistribusi normal

Tabel 4. Hasil Uji Normalitas Data

\begin{tabular}{|ccccc|}
\hline \multirow{2}{*}{$\begin{array}{c}\text { Aspek yang } \\
\text { diamati }\end{array}$} & \multicolumn{2}{l}{ Eksperimen } & Kontrol \\
\hline Lhitung & 0,1186 & 0,0939 & 0,1753 & Posttest \\
\hline Ltabel & 0,190 & & 0,1717 \\
\hline Kesimpulan & $\mathrm{L}_{0}<\mathrm{L}_{t}$ & $\mathrm{~L}_{0}<\mathrm{L}_{t}$ & $\mathrm{~L}_{0}<\mathrm{L}_{t}$ & $\mathrm{~L}_{0}<\mathrm{L}_{t}$ \\
\hline Keterangan & Data Berdistriusi Normal & \\
\hline
\end{tabular}

Berdasarkan tabel tersebut diperolehhasil bahwa pada kelas eksperimen menunjukkan $L_{\text {hitung }}$ data pretest dan posttest $(0,1186$ dan 0,0939$)$ lebih kecil dari $L$ table $(0,190)(n=20,=0,05)$ dan kelas kontrol menunjukkan $L_{\text {hitung }}$ data pretest dan posttest $(0,1753$ dan 0,1717$)$ lebih kecil dari $\mathrm{L}$ tabel $(0,190)(n=20,=0,05)$ dan dapat disimpulkan bahwa data pretest dan posttest kedua kelas berdistribusi normal. 


\section{Uji Homogenitas}

Uji homogenitas menggunakan uji $\mathrm{F}$ yang bertujuan untuk melihat data pretest dan posttest dari kedua kelas memiliki variansi yang homogen/tidak. Hasil pengujian homogenitas dapat dilihat pada tabel dibawah ini.

Tabel 5. Hasil Uji Homogenitas Data

\begin{tabular}{c|cc|c}
\hline Aspek yang diamati & \multicolumn{2}{|c|}{ Pretest } & Posttest \\
\hline Fhitung & 2,14 & $\mathbf{2 , 1 6}$ \\
\hline Ftabel & \multicolumn{2}{c}{$\mathbf{2 . 1 7}$} \\
\hline Kesimpulan & \multicolumn{2}{c}{ FhitungFtabel } \\
\hline Keterangan & \multicolumn{2}{c}{$\begin{array}{c}\text { Data Bervarians } \\
\text { Homogen }\end{array}$} \\
\hline
\end{tabular}

Perhitungan harga $\mathrm{F}$ dengan taraf signifikan 0,05 dari tabel distribusi Fternyata diperoleh Fhitung pretest sebesar 2,14 dan diperoleh $\mathrm{F}_{\text {hitung }}$ posttest sebesar 2,16. Hasil

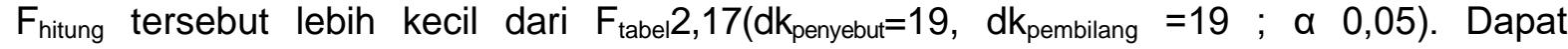
disimpulkan bahwa data pretest dan posttest kedua kelas memiliki variansi yang homogen pada tingkat kepercayaan $95 \%$.

\section{Uji Hipotesis}

Uji HipotesisPosttest

Berikut hasil perhitungan uji-t dataposttest dari kedua kelas sampel.

Tabel 6. Hasil Uji Hipotesis Posttest (uji-t)

\begin{tabular}{|c|c|c|}
\hline Keterangan & Posttest & \\
\hline Kelas & Eksperimen & Kontrol \\
\hline $\mathbf{N}$ & 20 & 20 \\
\hline Rata-rata & 76,60 & 65,50 \\
\hline Thitung & \multicolumn{2}{|c|}{2,33} \\
\hline Ttabel & \multicolumn{2}{|c|}{2.024} \\
\hline Kesimpulan & \multicolumn{2}{|c|}{ Terdapat pengaruh } \\
\hline
\end{tabular}

Dari hasil uji t tersebut diperoleh nilai Thitung untuk nilai posttest $=2,33$ dan Ttabel $=$ 2,024 dengan taraf signifikasi 0.05 dan derajat kebebasan $(\mathrm{df} / \mathrm{db}=20+20-2=38$ ) ini menunjukan bahwa Thitung > Ttabel atau 2,33> 2,024 dengan demikian maka Ho ditolak, Ha diterima maka dapat dikatakan bahwa data posttest atau tes akhir menunjukan adanya pengaruh pada pendekatan Value Clarification Technique (VCT) model matriks yang digunakan dalam penelitian ini.

\section{Pembahasan}

Hasil penelitian menunjukkan bahwa adanya pengaruh antara penggunaan pendekatanValue Clarification Technique (VCT) model matriks denganpenggunaan pembelajaran konvensional terhadap hasil belajar tematik terpadu. Terbukti dengan hasil uji hipotesis yang menyatakan menolak $\mathrm{H}_{0}$ pada taraf signifikansi $5 \%$. Peneliti menggunakan preetest dan posttest untuk mengetahui kemampuan pengetahuan sebelum dan sesudah diberi perlakuan dengan pendekatan Value Clarification Technique (VCT) model matriksdi kelas eksperimen.

Berdasarkan hasil analisis data pretest diperoleh bahwa data kedua kelas berdistribusi normal. Pengujian homogenitas sesudah pemberian perlakuan menunjukkan bahwa seluruh kelas memiliki varian yang homogen. 
Setelah dilaksanakan pembelajaran masing - masing kelas diberi posstest untuk mengetahui hasil pengetahuan belajar siswa. Berdasarkan hasil posttest siswa pada kelompok eksperimen memperoleh nilai rata-rata 76,60 dan siswa kelompok kontrol memperoleh nilai rata-rata 65,50. Hal ini karena pendekatan Value Clarification Technique (VCT) model matriks akan menciptakan suasana belajar yang aktif dengan mendorong siswa untuk mengemukakan pendapat. Keadaan seperti ini akan membuat pembelajaran semakin bermakna bagi siswa. Dalam pembelajaran yang menerapkan pendekatan Value Clarification Techniquemodel Matriksmelibatkan siswa secara aktif untuk menganalisis suatu permasalahan yang diberikan dalam bentuk daftar matriks. Hal ini sesuai dengan pendapat ahli yang mengatakan bahwa pendekatanValue Clarification Techniquemodel Matriks merupakan pendekatan pembinaan nilai sikap pada diri siswa melalui proses mencari, menentukan dan menganalisis suatu nilai yang dianggap baik oleh siswa.(Taniredja : 2015).

Pembelajaran dengan pendekatanValue Clarification Technique (VCT) model matriks diawali oleh guru pemberian daftar matriks mengenai materi pokok yang akan dipelajari. Siswa diberike sempatan membaca dan mempelajari daftar matriks tersebut. Langkah akhir dari pendekatan Value Clarification Technique (VCT) model matriks adalah guru bersamasama siswa merumuskankesimpulan dan pengarahan guru mengembalikan butir-butir sikap ke materi/konsep.

Sesuai dengan pendapat Djahiri (dalam Reinita, 2017) berpendapat bahwa langkahlangkah PendekatanValue Clarification TechniqueModel Matriks sebagai berikut: a. Fase Persiapan: (guru membuat media stimulus daftar), b. Fase Proses Pembelajaran: (diawali dengan penjelasan seperlunya) dilanjutkan dengan : I). Daftar stimulus disampaikan baik secara individual maupun klasikal (diprint atau ditulis di papan tulis), 2). Pengisian butir-butir yang beftautan dengan topik / tema (digali bersanta siswa), 3). Pengisian jawaban oleh siswa secara individual dan disusul oleh pengisian jawaban kelompok (dimana siswa) belajar menilai pendapat orang lain dan pendapatnya sendiri), 4)- Penyampaian hasil kerja sub 2 dan3 yang oleh guru direkan / ditulis di papan tulis (belum ada komentar / penilaian), 5). Mencari Klarifikasi, Argument jawaban baik individual kelompok maupun klasikal (peran guru untuk memperjelas dan memanipulasi sangat penting), 6). Pengambilan kesimpulan (bersama) dan pengarahan: guru mengembalikan butir-butir sikap ke materi / konsep. c, Tindak lanjut I). Remedial / perbaikan bagi yang kurang atau pengayaan bagi yang sudah baik. 2). Latihan pemantapan.

Sedangkan siswa yang dibelajarkan dengan model pembelajaran konvensional, dimana siswa menerima materi pelajaran secara pasif dari guru yang aktif menyampaikan pemebelajaran. Hal inilah yang menyebabkan perbedaan nilai tes hasil belajar tematik terpadu siswa di kelas eksperimen yang diajar menggunakan Pendekatan Value Clarification TechniqueModel Matriksdengan nilai tes hasil belajar tematik terpadu siswa yang diajar menggunakan pembelajaran konvensional.

Selanjutnya, berdasarkan data posttest yang normal dan homogen, maka dapat dilakukan pengujian hipotesis dengan menggunakan uji-t. Hasil pengujian hipotesis diperoleh thitung sebesar 2,33 dan tabel pada taraf kepercayaan $95 \%(\alpha=0.05)$ adalah sebesar 2,024. Sehingga $t_{\text {hitung }}>t_{\text {tabel }}(2,33>2,024)$, sehingga Ho ditolak dan $\mathrm{H}_{1}$ diterima, sehingga dapat disimpulkan bahwa penelitian ini dapat memberikan pengaruh yang signifikan terhadap hasil belajar siswa. Berdasarkan hasil pengujian hipotesis dapat diketahui bahwa terdapat pengaruh yang signifikan penggunaan PendekatanValue Clarification TechniqueModel Matriksterhadap hasil belajar tematik terpadu siswa kelas IV SD Negeri 05 Pasar Baru Kecamatan Bayang Pesisir Selatan.

\section{SIMPULAN}

Berdasarkan hasil analisis data penelitian yang telah dilakukan, maka dapat disimpulkan PendekatanValue Clarification TechniqueModel Matriksberpengaruh terhadap hasil belajar tematik terpadu kelas IV SD Negeri 05 Pasar Baru Kecamatan Bayang Psisir Selatan. Hal ini dibuktikan dari rata-rata posttest siswa di kelas eksperimen lebih tinggi dibandingkan kelas kontrol yaitu 76,60> 65,50. Selain itu hasil uji t dengan taraf signifikan 
0.05 menunjukkan bahwa $t_{\text {hitung }}>t_{\text {tabel }}(2,33>2,024)$. Berarti hipotesis $\mathrm{H}_{1}$ diterima dan $\mathrm{H}_{\mathrm{o}}$ ditolak, dalam arti kata bahwa terdapat perbedaan yang signifikan antara kemampuan pengetahuan hasil belajar tematik terpadu kelompok eksperimen yang menggunakan PendekatanValue Clarification TechniqueModel Matriksdan kelompok kontrol dengan menggunakan pembelajaran konvensional di SD Negeri 05 Pasar Baru Kecamatan Bayang Pesisir Selatan. Dengan demikian dapat disimpulkan bahwa Pendekatan Value Clarification TechniqueModel Matriksberpengaruh dan bagus digunakan pada pembelajaran tematik terpadu karena bisa meningkatkan hasil belajar siswa.

\section{DAFTAR PUSTAKA}

Abidin, Z. (2018). Hubungan Motivasi Belajar Dengan Hasil Belajar Pada Siswa Kelas V Sd Negeri Gugus Iv Kecamatan Banuhampu Kabupaten Agam. Jurnal Inovasi Pendidikan Dan Pembelajaran Sekolah Dasar, 2(2), 21. https://doi.org/10.24036/jippsd.v2i2.102701

Adisusilo, Sutarjo. 2014. Pembelajaran Nilai-Karakter Konstruktivisme dan VCT Sebagai Inovasi Pendekatan Pembelajaran Afektif. Jakarta: Rajawali Pers.

Arikunto, Suharsimi. 2009. Dasar-Dasar Evaluasi Pendidikan (Edisi Kedua). Jakarta: Bumi Aksara

Asep, Jihad. 2012. Evaluasi Pembelajaran. Yogyakarta: Multi Pressindo.

Faisal. (2014). Sukses Mengawali Kurikulum 2013 di SD (Teori dan Aplikasi. Yogyakarta: Dianda Creative.

Majid, Abdul. 2014. Pembelajaran Tematik Terpadu. Bandung: Remaja Rosdakarya.

REINITA. (2017). Pelatihan Pendekatan Value Clarification Technique Model Matriks Dalam Pembelajaran Pkn-Ips Bagi Guru Sd Kecamatan Talawi Sawahlunto. (2), 51-58.

Reinita, R., Suarman, F., \& Sakdiah, H. (2020). Mind mapping effect on the students' achievement in civic education for elementary school students. (Parikh 2016). https://doi.org/10.4108/eai.11-12-2019.2290898

Sugiyono. 2017. Metode Penelitian Kuantitatif, Kualitatf, dan R\&D. Bandung: Alfabeta.

Tukiran, Taniredja, Efi Miftah, \& Sri Harmianto. 2015. Model-Model Pembelajaran Inovatif. Bandung: Alfabeta 